\title{
Changing Treatment May Affect the Predictive Ability of European Treatment Outcome Study Scoring for the Prognosis of Patients with Chronic Myeloid Leukemia
}

\author{
Kronik Miyeloid Lösemi Hastalarında Tedavinin Değiştirilmesi Avrupa Tedavi İlem Çalışması \\ Prognoz Skorlamasındaki Tahmin Başarısını Etkileyebilir
}

Jing Huang, Leyan Wang, Lu Chen, He Qun, Xu Yajing, Chen Fangping, Zhao Xielan

Xiangya Hospital, Central South University, Department of Hematology, Changsha, China

\section{Abstract}

Objective: Previous studies compared the predictive ability of the European Treatment Outcome Study (EUTOS), Sokal, and Hasford scoring systems and demonstrated inconsistent findings with unknown reasons. This study was conducted to determine a useful scoring system to predict the prognosis of patients with chronic myeloid leukemia (CML) and identify the probable factors that affect the scoring.

Materials and Methods: This is a retrospective cohort study. The predictive ability of EUTOS and the factors that affect scoring were analyzed in 234 Chinese chronic-phase CML patients treated with frontline imatinib, including a few patients temporarily administered hydroxyurea for cytoreduction before imatinib. Patients were stratified into different risk groups according to each scoring system to assess the treatment outcomes and the predictive ability of EUTOS scores between patients who received imatinib during the entire followup period and patients who received altered treatment because of intolerance, progression, and treatment failure.

Results: Sixty-one (26.0\%) patients received altered treatments during the follow-up. In the EUTOS low- and high-risk groups, the 5 -year overall survival was $94.6 \%$ and $84.7 \%(p=0.011)$, 5 -year eventfree survival was $92.6 \%$ and $77.6 \%(p=0.001)$, and 5 -year progressionfree survival (PFS) was $95.3 \%$ and $82.4 \%(p=0.001)$, respectively. The predictive ability of EUTOS was better than that of the Sokal and Hasford scores ( $p=0.256, p=0.062, p=0.073)$ without statistical significance. All three scoring systems were valid in predicting early optimal response. Kaplan-Meier analysis showed a high association between overall PFS and the EUTOS scores in the standard-dose imatinib group $(\mathrm{p}<0.001)$.

Conclusion: This study suggests that the EUTOS scoring system could predict the outcome of chronic-phase CML patients treated with standard-dose imatinib. Altered treatment is a crucial factor that affects the prognostic impact of EUTOS scoring. Achieving complete cytogenetic response at 18 months is an essential factor in predicting the prognosis of patients with CML.

Keywords: Imatinib, Sokal score, Hasford score, European Treatment Outcome Study Score

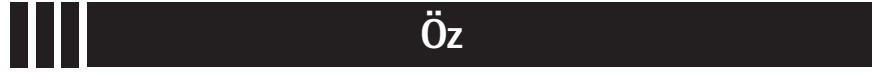

Amaç: Avrupa Tedavi İzlem Çalışması (EUTOS), Sokal ve Hasford skorlamalarının öngörüsel tahmin başarılarının karşılaştırıldığı çalışmalarda bilinmeyen nedenlerle tutarsız bulgular görülmektedir. $\mathrm{Bu}$ çalışma, kronik miyeloid lösemi (KML) hastalarının prognozunu tahmin edecek yararlı bir skorlama sistemi bulma ve skorlamayı etkileyen muhtemel faktörleri ortaya çıkartmak amacıyla yapılmıştır.

Gereç ve Yöntemler: Bu çalışma geriye dönük hasta grubunda yapılmıştır. İmatinib tedavisi gören 234 Çinli kronik faz KML hastasında (birkaç hasta imatinib tedavisi öncesi kısa süreli hidroksiüre tedavisi almıştır) EUTOS tahmin skorları ve bu skorlamayı etkileyen faktörler incelenmiştir. Tedavi çıktılarını ve EUTOS skorlarının tahmin başarısını belirlemek amacıyla tüm izlem boyunca imatinib alan ve intolerans, ilerleme ya da tedavi başarısızığı gibi nedenlerle farklı tedaviler alan hastalar, her skorlama sistemine göre değişik risk gruplarında sınıflandırılmıştır.

Bulgular: Takip sürecinde hastaların 61 tanesinde (\%26) tedavi değişikliği olmuştur. EUTOS düşük ve yüksek risk gruplarında 5 yıllık genel sağkalım sırasıyla \%94,6 ve $\% 84,7(p=0,011)$, hastalıksız sağkalım $\% 95,3$ ve $\% 82,4$ ( $p=0,001)$ ve progresyonsuz sağkalım \%95,3 ve \%77,6 $(p=0,001)$ olarak bulunmuştur. EUTOS tahminleri, istatistiksel olarak anlamlı olmamakla beraber, Sokal ve Hasford skorlarından daha iyi görülmektedir ( $p=0,256, p=0,062, p=0,073)$. Her üç skorlama da erken optimal yanıtın değerlendirmesinde geçerli görülmektedir. KaplanMeier analizleri, standart doz imatinib kullanılan gruplarda, genel progresyonsuz sağkalım ve EUTOS skorları arasında yüksek anlamlılıkta bir ilişki göstermektedir $(p<0,001)$.

Sonuç: Bu çalışma EUTOS skorlama tahmin sisteminin, standart-doz imatinib ile tedavi edilen kronik faz KML hastalarının yanıtlarının değerlendirmesinde uygun olduğunu göstermektedir. Tedavi değişikliği, EUTOS skorlamasının prognostik değerlendirme sonucunu etkileyen önemli bir faktördür. KML hastalarının prognoz tahminleri etkileyen bir diğer önemli faktör de 18. ayda tam sitogenetik yanıta ulaşılmasıdır.

Anahtar Sözcükler: İmatinib, Sokal skoru, Hasford skoru, Avrupa Tedavi İzlem Çalışması skoru 


\section{Introduction}

As the firstline treatment for chronic myeloid leukemia (CML), imatinib is widely used after diagnosis and dramatically improves the overall survival (OS) of CML patients [1]. Predicting the prognosis is significant for the management of CML patients. Currently, the European Treatment Outcome Study (EUTOS), Hasford, and Sokal prognostic scoring systems are used for predicting the prognosis of CML patients $[2,3,4]$. The EUTOS scoring system is a novel prognostic scoring system that challenges the conventional Sokal and Hasford scoring systems in predicting the outcome of CML patients. However, recent studies examining the effectiveness of the EUTOS scoring system in predicting the prognosis of CML patients showed controversial results. For example, several studies from different regions of the world compared the clinical significance of the three prognostic scoring systems. Five studies found that EUTOS was better than the Hasford and Sokal systems in predicting the prognosis of CML patients $[1,2,3,5,6]$. In contrast, 3 studies showed that the EUTOS score does not predict prognosis in CML patients $[7,8,9]$. It is currently unknown what factors caused these controversial findings.

The purpose of this study was to compare the predictive ability of the Sokal, Hasford, and EUTOS prognostic scoring systems by stratifying CML-chronic-phase (CP) patients who received firstline imatinib mesylate at diagnosis into different risk groups. The possible factors that affect the prognostic ability of EUTOS were further explored according to the three scoring systems.

\section{Materials and Methods}

\section{Patients}

A total of 234 CML-CP patients (162 males, 72 females) who received imatinib mesylate (Novartis Oncology, Novartis Pharma Stein AG, Stein, Switzerland) treatment within 6 months of diagnosis at X Hospital between January 2004 and July 2014 were recruited for this study. CML-CP was diagnosed according to published diagnostic criteria [10], and all patients were treated with a standard dose of imatinib ( $400 \mathrm{mg} /$ day) over 3 months. No other treatment was given, except for hydroxyurea temporarily administered for cytoreduction before imatinib in 9 patients.

\section{Calculations of the Chronic Myeloid Leukemia Prognostic Indexes}

The Sokal score was calculated using the following formula: Exp $0.0116 \times$ (age in years-43.4) $+0.0345 \times$ (spleen size-7.51) $+0.188 \times\left[(\text { platelet count } / 700)^{2}-0.563\right]+0.0887 \times$ (blast cells-2.10). Patients with a score of less than 0.8 were assigned to the low Sokal risk group, patients with a score from 0.8 to 1.2 were assigned to the intermediate Sokal risk group, and patients with a score greater than 1.2 were assigned to the high Sokal risk group [11]. The Hasford score was calculated as follows: 0.666 (when age $>50$ years $)+(0.042 \times$ spleen size $)+1.0956$ (when platelet count $\left.>1500 \times 10^{9} / \mathrm{L}\right)+(0.0584 \times$ blast cell count) +0.20399 (when basophil count $>3 \%)+(0.0413 \times$ eosinophil count) $\times 100$. Patients with a score of less than 780 were assigned to the low Hasford risk group, patients with a score from 781 to 1480 were assigned to the intermediate Hasford risk group, and patients with a score higher than 1480 were assigned to the high Hasford risk group [12]. The EUTOS score was calculated as follows: ( $7 \times$ basophil count) + (4xspleen size), where the spleen was measured in centimeters below the costal margin and basophils as a percentage rate. Patients with a EUTOS score higher than 87 were assigned to the high EUTOS risk group, while patients with a EUTOS score of less than or equal to 87 were assigned to the low EUTOS risk group [10].

\section{Definitions}

OS: the length of time from the date of diagnosis to the date of death or final follow-up (1 July 2014).

Event-free survival (EFS): the length of time from the date of initiating imatinib therapy to the date of failure according to the European Leukemia Net criteria, the date of stopping treatment due to imatinib intolerance, or the date of last follow-up in patients whose treatments did not fail [13].

Progression-free survival (PFS): the length of time from the date of imatinib therapy initiation to the date of progression to accelerated phase (AP)/blastic phase (BP) or to the date of death.

Complete cytogenetic response (CCyR): no Philadelphia chromosome was detected in the patient by G-banding analysis of bone marrow and no Philadelphia cell was detected in the patient when using fluorescence in situ hybridization analysis of peripheral blood.

Partial cytogenetic response (PCyR): 1\%-35\% Philadelphia chromosome in a patient's bone marrow.

Major molecular response (MMR): the achievement of $\geq 3$ logs reduction in BCR-ABL mRNA from the standardized baseline $[14,15,16,17]$.

\section{Statistical Analysis}

Data were analyzed using SPSS 17.0 (SPSS Inc., Chicago, IL, USA). Normally distributed continuous variables were presented as mean \pm standard deviation, and non-normally distributed continuous variables were presented as medians with interquartile ranges. Kaplan-Meier methods and log rank tests were applied to analyze the time-to-event data. The 5-year $E F S, P F S$, and OS and the cumulative incidence of PCyR, CCyR, 
and MMR were compared using the chi-square test. A value of $p<0.05$ was considered statistically significant.

\section{Results}

\section{Baseline Characteristics}

The mean age at diagnosis was $40.3 \pm 13.2$ years. Median followup duration of imatinib treatment was 20.5 months (range: 9-120 months) months. The median duration from diagnosis of CML to imatinib initiation was 19 (range: 6-115) days. The CCyR rates at 12 months and 18 months were $56.4 \%$ and $65.4 \%$, respectively.

According to the EUTOS scoring system, 149 patients (63.7\%) were classified as low-risk and 85 patients (36.3\%) were classified as high-risk. Using the Sokal scoring system, 66, 70, and 98 patients were classified into low-, intermediate-, and high-risk groups, while 94, 93, and 47 patients were classified into low-, intermediate-, and high-risk groups when the Hasford scoring system was used. The baseline characteristics of patients with CML-CP are shown in Table 1.

\section{Outcomes}

The 5-year OS, EFS, and PFS of the 234 patients were $91.0 \%$, $87.2 \%$, and $90.6 \%$, respectively. The 5-year OS, EFS, and PFS were $94.6 \%$ and $84.7 \%(p=0.011), 92.6 \%$ and $77.6 \%(p=0.001)$, and $95.3 \%$ and $82.4 \%(\mathrm{p}=0.001)$ for low and high EUTOS risk groups, respectively. Significant differences in 5-year OS, EFS, and PFS were observed between the low EUTOS and high EUTOS risk groups. However, there were no significant differences between groups classified by the Sokal $(p=0.137, p=0.106$, $p=0.110$, respectively) and Hasford ( $p=0.256, p=0.062, p=0.073$, respectively) prognostic scoring systems. Moreover, KaplanMeier analysis of OS, EFS, and PFS showed significant differences between the low and high EUTOS risk groups $(p<0.001$, $p<0.001, p<0.001$ ) (Figure 1), but no significant difference was
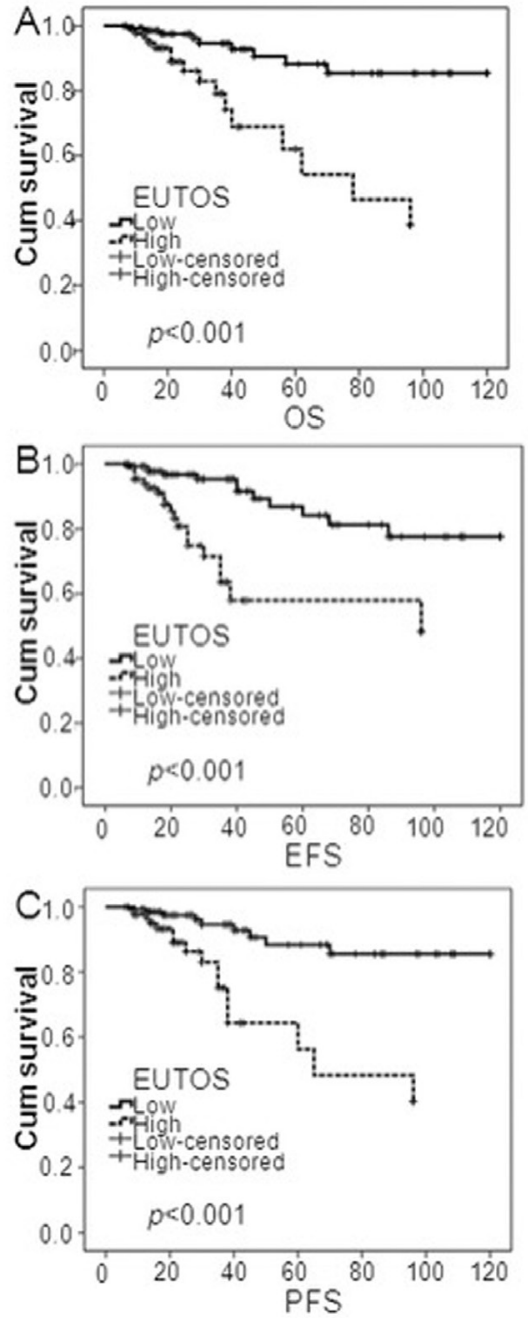

Figure 1. Overall survival, event-free survival, and progressionfree survival using the European Treatment Outcome Study score system. There was a significant difference in overall survival (A), event-free survival (B), and progression-free survival (C) between the risk groups $(p<0.001, p<0.001, p<0.001)$.

EUTOS: European Treatment Outcome Study, OS: overall survival, EFS: event-free survival, PFS: progression-free survival.

\begin{tabular}{|l|l|}
\hline Table 1. Clinical characteristics of patients at diagnosis (n=234). \\
\hline Clinical Characteristics & Median (Range) \\
\hline WBC $(/ \mu \mathrm{L})$ & $167,550.0(6900.0-638,200.0)$ \\
\hline Platelet count $/ \mu \mathrm{L})$ & $459,830.0(68,000.0-1,515,000.0)$ \\
\hline Basophils $(\%)$ & $3.8(0.0-19.3)$ \\
\hline Spleen size (centimeters below the costal margin) & $8.0(0.0-24.0)$ \\
\hline Clinical characteristics & Mean \pm standard deviation \\
\hline Age (years) & $40.3 \pm 13.2$ \\
\hline Hemoglobin (g/dL) & $107.4 \pm 22.5$ \\
\hline Eosinophils $(\%)$ & $2.3 \pm 2.2$ \\
\hline $\begin{array}{l}\text { According to the normality test, the statistics of age, hemoglobin, and Eosinophils corresponded to a normal distribution, while white blood cells, platelet cells, blasts, basophils, and } \\
\text { spleen size corresponded to a non-normal distribution. } \\
\text { WBC: White blood cell. }\end{array}$ \\
\hline
\end{tabular}


found between Sokal groups $(p=0.335, p=0.123, p=0.170$ for low, intermediate-, and high-risk groups) or Hasford groups ( $p=0.135, p=0.057, p=0.052$ for low-, intermediate- , and highrisk groups).

The overall rates of PCyR at 3 months, CCyR at 12 months and 18 months, and MMR at 18 months for all CML patients were $18.4 \%, 56.4 \%, 65.4 \%$, and $46.2 \%$, respectively. Furthermore, 131 patients (87.9\%) and 22 patients (25.9\%) achieved CCyR at 18 months in the low and high EUTOS risk groups ( $p<0.001) ; 60$ patients (90.9\%), 59 patients (84.3\%), and 34 patients (34.7\%) achieved CCyR at 18 months in the low, intermediate, and high Sokal risk groups $(p<0.001)$, respectively; and $84(89.4 \%), 57$ (61.3\%), and 12 patients (25.5\%) achieved CCyR at 18 months in the low, intermediate, and high Hasford risk groups $(p<0.001)$, respectively. As shown in Table 2, PCyR was significantly validated at 3 months in all 3 prognostic scoring systems $(p<0.001), C C y R$ was significantly validated at 12 months and 18 months $(p<0.001)$, and MMR was significantly validated at 18 months in all 3 prognostic scoring systems $(p<0.001)$.

Overall, of the $234 \mathrm{CML}-\mathrm{CP}$ patients, 173 patients (73.9\%) were treated with the standard dose $(400 \mathrm{mg})$ of imatinib, while 61 patients (26.0\%) received altered treatments because of intolerance, progression, or treatment failure. The rates of 5-year PFS were $97.5 \%$ and $87.3 \%(p=0.012)$ for patients treated with standard-dose imatinib in the EUTOS low-risk $(118,68.2 \%)$ and high-risk $(55,31.7 \%)$ groups, but only $87.1 \%$ and $73.3 \%(p=0.176)$ for patients who received altered treatments in low $(31,50.8 \%)$ and high EUTOS risk groups $(30,49.1 \%)$, respectively.
There were significant differences in 5-year OS between low and high EUTOS risk score groups in patients that received standard-dose imatinib treatment (97.5\% and 89.1\%, $\mathrm{p}=0.03)$, whereas it was not different in the patients who received altered treatments ( $83.9 \%$ and $76.7 \%, p=0.479)$. Furthermore, KaplanMeier analysis showed a high association between overall PFS and EUTOS scores in patients who received standard-dose imatinib treatment $(p<0.001)$, but no significant correlation in patients who received altered treatment $(p=0.246)$ (Figure 2$)$.

\section{Discussion}

Previous studies presented controversial findings on whether EUTOS is more useful in predicting the survival of CML patients than the Sokal and Hasford scoring systems. This study demonstrated that the EUTOS, Hasford, and Sokal scoring systems were all effective in predicting early optimal response (PCyR at 3 months, CCyR at 12 months and 18 months, and MMR at 18 months) in CML-CP patients who were treated with imatinib as frontline therapy, but the EUTOS scoring system was more effective as a prognostic indicator of OS, EFS, and PFS than the Sokal and Hasford scoring systems. A novel finding in this study is that altered treatment is a key factor that affects the prognostic ability of the EUTOS scoring system.

Among the 3 studies not supporting the predictive effect of EUTOS in the prognosis of CML patients $[7,8,9], 33.6 \%$ of 282 CML-CP patients in the study of Marin et al. were treated with imatinib as frontline therapy, but the treatment was changed to a second-generation tyrosine kinase inhibitor ( $\left.2^{\text {nd }} \mathrm{TKI}\right)$ [9]. In the study of Jabbour et al. [8], 84.7\% of $465 \mathrm{CML}-\mathrm{CP}$ patients were

Table 2. Comparison of Sokal, Hasford, and European Treatment Outcome Study scores for curative effects.

\begin{tabular}{|c|c|c|c|c|c|}
\hline & n (\%) & 3m-PCyR (\%) & $12 \mathrm{~m}-\mathrm{CCyR}(\%)$ & 18m-CCyR (\%) & $18 \mathrm{~m}-\mathrm{MMR}(\%)$ \\
\hline Low & $149(63.7)$ & 26.2 & 75.8 & 87.9 & 63.8 \\
\hline High & $85(36.3)$ & 4.7 & 22.4 & 25.9 & 15.3 \\
\hline Sokal & & $p<0.001$ & $\mathrm{p}<0.001$ & $p<0.001$ & $p<0.001$ \\
\hline Intermediate & $70(29.9)$ & 21.4 & 62.9 & 84.3 & 58.6 \\
\hline High & 98 (41.9) & 4.1 & 31.6 & 34.7 & 19.4 \\
\hline Hasford & & $p<0.001$ & $p<0.001$ & $p<0.001$ & $p<0.001$ \\
\hline Low & $94(40.2)$ & 31.9 & 76.6 & 89.4 & 63.8 \\
\hline All patients & $234(100)$ & 18.4 & 56.4 & 65.4 & 46.2 \\
\hline
\end{tabular}

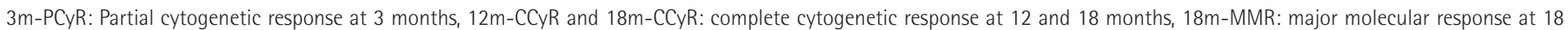
months, EUTOS: European Treatment and Outcome Study. 


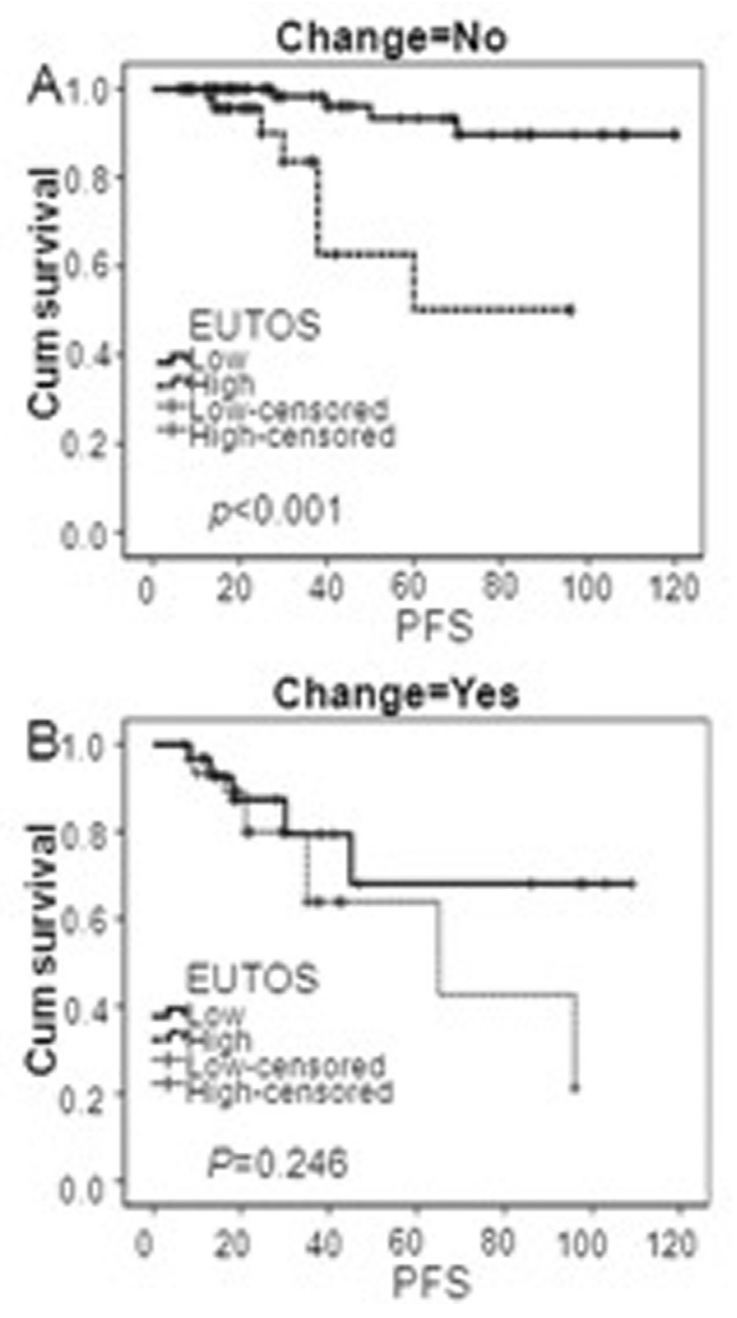

Figure 2. Progression-free survival using European Treatment Outcome Study score for chronic myeloid leukemia-chronicphase patients who received imatinib or altered treatment. (A) Progression-free survival using European Treatment Outcome Study score for chronic myeloid leukemia-chronic-phase patients treated with standard-dose imatinib. There was a significant difference between the risk groups $(p<0.001)$. (B) Progressionfree survival using European Treatment Outcome Study score for chronic myeloid leukemia-chronic-phase patients who received altered treatment. There was no significant difference between the risk groups $(p=0.246)$.

treated with high-dose imatinib (44.7\%) and a $2^{\text {nd }}$ TKI (40\%) at diagnosis. In the study of Yamamoto et al., poor patient adherence to imatinib therapy was mentioned [7]. Among the studies supporting a positive effect of EUTOS in predicting the prognosis of CML patients, only $21.0 \%$ of $1288 \mathrm{CML}$ patients in the study of Hoffmann et al. [18] and 25.0\% of 2060 patients in the study of Hasford et al. [6] received high-dose imatinib (600-800 mg), while no patients received $2^{\text {nd }}$ TKI therapy. In this study, 26.0\% patients received altered treatment during followup $(20.5 \%$ received low-dose imatinib; 5.5\% were switched to a $2^{\text {nd }} \mathrm{TKI}$ ). The percentage of patients receiving altered treatments in our study is comparable to those of the studies supporting a positive effect of EUTOS, but lower than that of studies supporting a negative effect. In this study, we found that 5-year PFS and OS had no significant correlations with EUTOS scores in patients who received altered treatments, but they were significantly associated with EUTOS scores in patients without altered treatments. Thus, changing treatment may be a key factor that affects the predictive ability of EUTOS. In addition, the percentage of patients in the high EUTOS risk group was small in the three negative studies $(11.2 \%$ in the Marin et al. [9] study, $8 \%$ in the Jabbour et al. [8] study, and 11\% in the Yamamoto et al. [7] study), while it was high (36.3\%) in the present study. We propose that the small number of patients in the high-risk group in the three negative studies may have caused a bias.

The end-points for assessment of the EUTOS scoring system may also influence the conclusions. The majority of previous studies analyzed the overall CCyR, but only 3 reports $[6,7,18]$ assessed CCyR at 18 months. In this study, the OS, EFS, and PFS were evaluated as long-term response, while PCyR at 3 months, CCyR at 12 months and 18 months, and MMR at 18 months were evaluated as early optimal response according to the 2013 National Comprehensive Cancer Network guidelines. This study demonstrated that the rates of 5-year PFS in patients achieving CCyR at 18 months was significantly higher than that in patients not achieving CCyR at 18 months (99.3\% vs. 74.1\%, $\mathrm{p}<0.001)$. Therefore, CML patients who did not achieve CCyR at 18 months were more likely to progress AP/BP or death and CCyR at 18 months should be considered as an essential end-point to assess the survival of CML patients.

\section{Conclusion}

In conclusion, the EUTOS prognostic scoring system is an effective prognostic tool in assessing the outcome of CML-CP patients who were treated with standard-dose imatinib. Altered treatment should be considered as a key factor when using the EUTOS scoring system. CCyR at 18 months during therapy is an essential end-point to assess the survival of CML-CP patients. Our findings may have important clinical implications, but they should be confirmed in a larger cohort and validated in a prospective observational study.

\section{Acknowledgments}

We are thankful to Fu Bin for revising the manuscript. This work did not receive any specific grant from any funding agency in the public, commercial, or not-for-profit sector.

\section{Ethics}

Ethics Committee Approval: This is a retrospective cohort study; Informed Consent: This is a retrospective cohort study. 


\section{Authorship Contributions}

Concept: Zhao Xielan; Design: Zhao Xielan; Data Collection or Processing: Jing Huang, Leyan Wang, Lu Chen, He Qun, Xu Yajing, Chen Fangping, Zhao Xielan; Analysis or Interpretation: Jing Huang, Leyan Wang, Lu Chen, He Qun, Xu Yajing, Chen Fangping, Zhao Xielan; Literature Search: Jing Huang; Writing: Jing Huang.

Conflict of Interest: The authors of this paper have no conflicts of interest, including specific financial interests, relationships, and/or affiliations relevant to the subject matter or materials included.

\section{References}

1. Yahng SA, Jang EJ, Choi SY, Lee SE, Kim SH, Kim DW. Prognostic discrimination for early chronic phase chronic myeloid leukemia in imatinib era: comparison of Sokal, Euro, and EUTOS scores in Korean population. Int J Hematol 2014;100:132-140.

2. Tao Z, Liu B, Zhao Y, Wang Y, Zhang R, Han M, Zhang L, Li C, Ru K, Mi Y, Wang J. EUTOS score predicts survival and cytogenetic response in patients with chronic phase chronic myeloid leukemia treated with first-line imatinib. Leuk Res 2014;38:1030-1035.

3. Bonifacio M, Binotto G, Calistri E, Maino E, Tiribelli M; Gruppo Triveneto LMC. EUTOS score predicts early optimal response to imatinib according to the revised 2013 ELN recommendations. Ann Hematol 2014;93:163-164.

4. Uz B, Buyukasik $Y$, Atay $H$, Kelkitli E, Turgut $M$, Bektas O, Eliacik E, Isik A, Aksu S, Goker H, Sayinalp N, Ozcebe OI, Haznedaroglu IC. EUTOS CML prognostic scoring system predicts ELN-based 'event-free survival' better than Euro/Hasford and Sokal systems in CML patients receiving front-line imatinib mesylate. Hematology 2013;18:247-252.

5. Hoffmann V, Baccarani M, Hasford J, Guilhot J, Saussele S, Rosti G, Guilhot F, Porkka K, Ossenkoppele G, Lindoerfer D, Simonsson B, Pfirrmann $M$, Hehlmann R. The EUTOS CML score aims to support clinical decisionmaking. Blood 2012;119:2966-2967.

6. Hasford J, Baccarani M, Hoffmann V, Guilhot J, Saussele S, Rosti G, Guilhot F, Porkka K, Ossenkoppele G, Lindoerfer D, Simonsson B, Pfirrmann M, Hehlmann R. Predicting complete cytogenetic response and subsequent progression-free survival in 2060 patients with CML on imatinib treatment: the EUTOS score. Blood 2011;118:686-692.

7. Yamamoto E, Fujisawa $S$, Hagihara M, Tanaka M, Fujimaki K, Kishimoto $K$, Hashimoto C, Itabashi M, Ishibashi D, Nakajima Y, Tachibana T, Kawasaki R, Kuwabara H, Koharazawa H, Yamazaki E, Tomita N, Sakai R, Fujita H, Kanamori H, Ishigatsubo Y. European Treatment and Outcome Study score does not predict imatinib treatment response and outcome in chronic myeloid leukemia patients. Cancer Sci 2014;105:105-109.

8. Jabbour E, Cortes J, Nazha A, O'Brien S, Quintas-Cardama A, Pierce S, Garcia-Manero G, Kantarjian H. EUTOS score is not predictive for survival and outcome in patients with early chronic phase chronic myeloid leukemia treated with tyrosine kinase inhibitors: a single institution experience. Blood 2012;119:4524-4526.
9. Marin D, Ibrahim AR, Goldman JM. European Treatment and Outcome Study (EUTOS) score for chronic myeloid leukemia still requires more confirmation. J Clin Oncol 2011;29:3944-3945.

10. Kantarjian HM, Talpaz M, O'Brien S, Smith TL, Giles FJ, Faderl S, Thomas DA, Garcia-Manero G, Issa JP, Andreeff M, Kornblau SM, Koller C, Beran M, Keating M, Rios MB, Shan J, Resta D, Capdeville R, Hayes K, Albitar M, Freireich EJ, Cortes JE. Imatinib mesylate for Philadelphia chromosomepositive, chronic-phase myeloid leukemia after failure of interferon-alpha: follow-up results. Clin Cancer Res 2002;8:2177-2187.

11. Sokal JE, Cox EB, Baccarani M, Tura S, Gomez GA, Robertson JE, Tso CY, Braun TJ, Clarkson BD, Cervantes F, Rozman C; Italian Cooperative CML Study Group. Prognostic discrimination in "good-risk" chronic granulocytic leukemia. Blood 1984;63:789-799.

12. Hasford J, Pfirrmann M, HehImann R, Allan NC, Baccarani M, Kluin-Nelemans JC, Alimena G, Steegmann JL, Ansari H. A new prognostic score for survival of patients with chronic myeloid leukemia treated with interferon alfa. Writing Committee for the Collaborative CML Prognostic Factors Project Group. J Natl Cancer Inst 1998;90:850-858.

13. Baccarani M, Cortes J, Pane F, Niederwieser D, Saglio G, Apperley J, Cervantes $F$, Deininger $M$, Gratwohl A, Guilhot $F$, Hochhaus A, Horowitz $M$, Hughes T, Kantarjian $H$, Larson R, Radich J, Simonsson B, Silver RT, Goldman J, Hehlmann R; European LeukemiaNet. Chronic myeloid leukemia: an update of concepts and management recommendations of European LeukemiaNet. J Clin Oncol 2009;27:6041-6051.

14. Ohnishi $K$, Nakaseko C, Takeuchi J, Fujisawa $S$, Nagai T, Yamazaki H, Tauchi T, Imai K, Mori N, Yagasaki F, Maeda Y, Usui N, Miyazaki Y, Miyamura K, Kiyoi H, Ohtake S, Naoe T; Japan Adult Leukemia Study Group. Long-term outcome following imatinib therapy for chronic myelogenous leukemia, with assessment of dosage and blood levels: the JALSG CML202 study. Cancer Sci 2012;103:1071-1078.

15. Yagasaki F, Niwa $T$, Abe A, Ishikawa M, Kato C, Ogura K, Sasaki H, Kyo T, Jinnai I, Bessyo M, Miyamura K. Correlation of quantification of major bcrabl mRNA between TMA (transcription mediated amplification) method and real-time quantitative PCR. Rinsho Ketsueki 2009;50:481-487 (in Japanese with English abstract).

16. O'Brien SG, Guilhot F, Larson RA, Gathmann I, Baccarani M, Cervantes F, Cornelissen JJ, Fischer T, Hochhaus A, Hughes T, Lechner $K$, Nielsen JL, Rousselot P, Reiffers J, Saglio G, Shepherd J, Simonsson B, Gratwohl A, Goldman JM, Kantarjian H, Taylor K, Verhoef G, Bolton AE, Capdeville R, Druker BJ; IRIS Investigators. Imatinib compared with interferon and low-dose cytarabine for newly diagnosed chronic-phase chronic myeloid leukemia. N Engl J Med 2003;348:994-1004.

17. Langabeer SE, Gale RE, Harvey RC, Cook RW, Mackinnon S, Linch DC. Transcription-mediated amplification and hybridisation protection assay to determine BCR-ABL transcript levels in patients with chronic myeloid leukaemia. Leukemia 2002;16:393-399.

18. Hoffmann VS, Baccarani M, Lindoerfer $D$, Castagnetti $F$, Turkina A, Zaritsky A, Hellmann A, Prejzner W, Steegmann JL, Mayer J, Indrak K, Colita A, Rosti G, Pfirrmann M. The EUTOS prognostic score: review and validation in 1288 patients with CML treated frontline with imatinib. Leukemia 2013;27:20162022. 